\title{
Eesti keele lektorina Oulus
}

\author{
VALVE-LIIVI KINGISEPP
}

Kokkuvõte. Kirjutise autor töötas aastail 1988-1992 eesti keele lektorina Oulu ülikoolis ja selgitab, kuidas toimus 1980. aastatel Moskva kaudu lektorite tööle suunamine, missuguseid ainekursusi tuli lugeda, õpetada, kuidas võtsid üliõpilased pakutut vastu, missuguseks kujunes teadustöö kateedris, lektorite seminaridel, ettekanded, kaastöö väljaannetele, eesti keele päeva korraldamine jm. Samas iseloomustatakse lektori tegevust väljaspool ülikooli Eesti iseseisvumisliikumise ajal, meeldejäävaid kokkupuuteid kohalikega, intensiivset õpetustegevust rahvaülikoolides, eesti keele ja kultuuri tutvustamist suveülikoolides, koolides.

Võtmesõnad: eesti keele õpetus soomlastele; eesti-soome kultuurisuhted

Minu viimase tööaasta kevadel korraldasime soome ja saami keele kateedriga eesti keele päeva, millega tähistasime eesti keele õppe 25. aastapäeva Oulu ülikoolis. Kutsusime esinema kõik endised eesti keele lektorid ja ma palusin neil eelnevalt vastata kümnele küsimusele, mis tundusid tookord olulised. Aastaid hiljem palus mu järglane Heli Laanekask vastata mul endal samadele küsimustele. Seda ma tegingi ja jagan omi mõtteid nüüd lugejatega.

Oulu-aastaisse tagasi mõeldes kerkivad silme ette paljud erksad isiksused, asutused, sündmused, tähtpäevad ja kogu lugu kipub kätte nostalgiliste mälestuste esituseks, sest neid aastaid mäletan ju kui oma elu sisukamaid, huvitavamaid ja sündmusterikkamaid, millest võiks kirjutada pikalt, koos rikkaliku pildimaterjali, kirjade, dokumentide jm. 


\section{Millal töötasid Oulu ülikooli eesti keele lektorina?}

Töötasin Oulu ülikooli eesti keele lektorina 1. septembrist 1988 kuni 1. augustini 1992.

\section{Kuidas toimus tööle määramine?}

Lektorite valik käis 1980. aastatel ikka vanaviisi. Soome ja Nõukogude Liidu vahel sõlmitud tehnilise ja teadusliku koostöölepingu alusel küsis NSVL kõrghariduse ministeerium eesti keele lektori kandidaate Eesti NSV kõrg- ja keskhariduse ministeeriumist, kust omakorda informeeriti kõrgkoolide vastavaid instantse. Paralleelselt tegutsesid küsimusega julgeolekuorganid. Dekanaadist jõudis info lõpuks ka eriala kateedritesse. Mulle tehti ettepanek kandideerida eesti keele lektori kohale juba 1980. aastal. Täitsin kevadel vajalikud dokumendid, neid oli kolossaalselt palju, lisada tuli 13 fotot ja ülikooli välisosakonna töötaja kaudu liikusid need Tallinna ministeeriumisse. Juulis sain kutse ilmuda Moskvasse kõrgharidusministeeriumi väliskomisjoni istungile, kus referent tutvustas komisjoni liikmetele uut lektorikandidaati. Mulle esitati paar üsna väheütlevat küsimust ja referent konstateeris kiiresti, et hakkate tööle Jyväskylä ülikoolis. Järgnes veel päevane instrueerimisseminar, kus õpetati, kuidas tuleb välismaal käituda, et ei tohi üliõpilaste peale karjuda, uksi paugutades auditooriumist lahkuda jms. Nimelt olid koos välismaale tööle siirduvad vene keele lektorid, keda oli tõesti palju, ja ilmselt eeldati, et neile vajaminevate elementaarsete käitumisnormide õpetus kulub ära ka eesti keele lektorile.

Jõudnud koju, selgus varsti, et Jyväskylä lektor Toivo Kuldsepp jätkab seal tööd neljandat aastat ja mind sinna vaja ei ole. Uuel, 1981. aastal keegi minu vastu enam huvi ei tundnud. Jyväskylä uueks eesti keele lektoriks sai Heldi Tamme Tallinna pedagoogilisest instituudist. Mõnede eraviisiliste pärimiste peale sain teada, et Moskvas oli minu suhtes positiivne otsus tehtud enne, kui sinna laekus Eestist julgeolekuinstantsidega kooskõlastatud paber. EKP väliskomisjon ei pidanud minu välismaale 


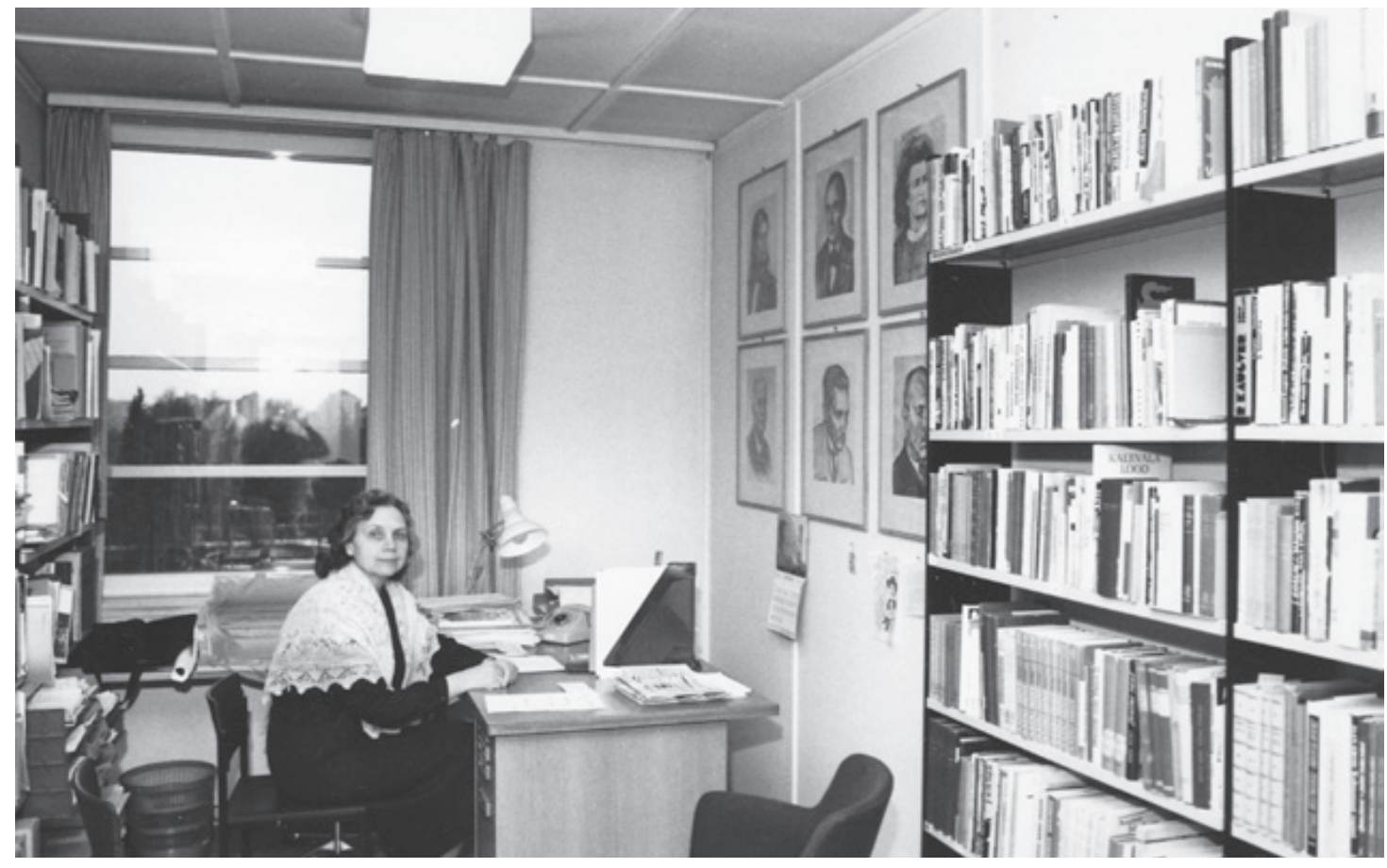

Eesti keele lektor oma tööruumis. Foto Karl Sandman

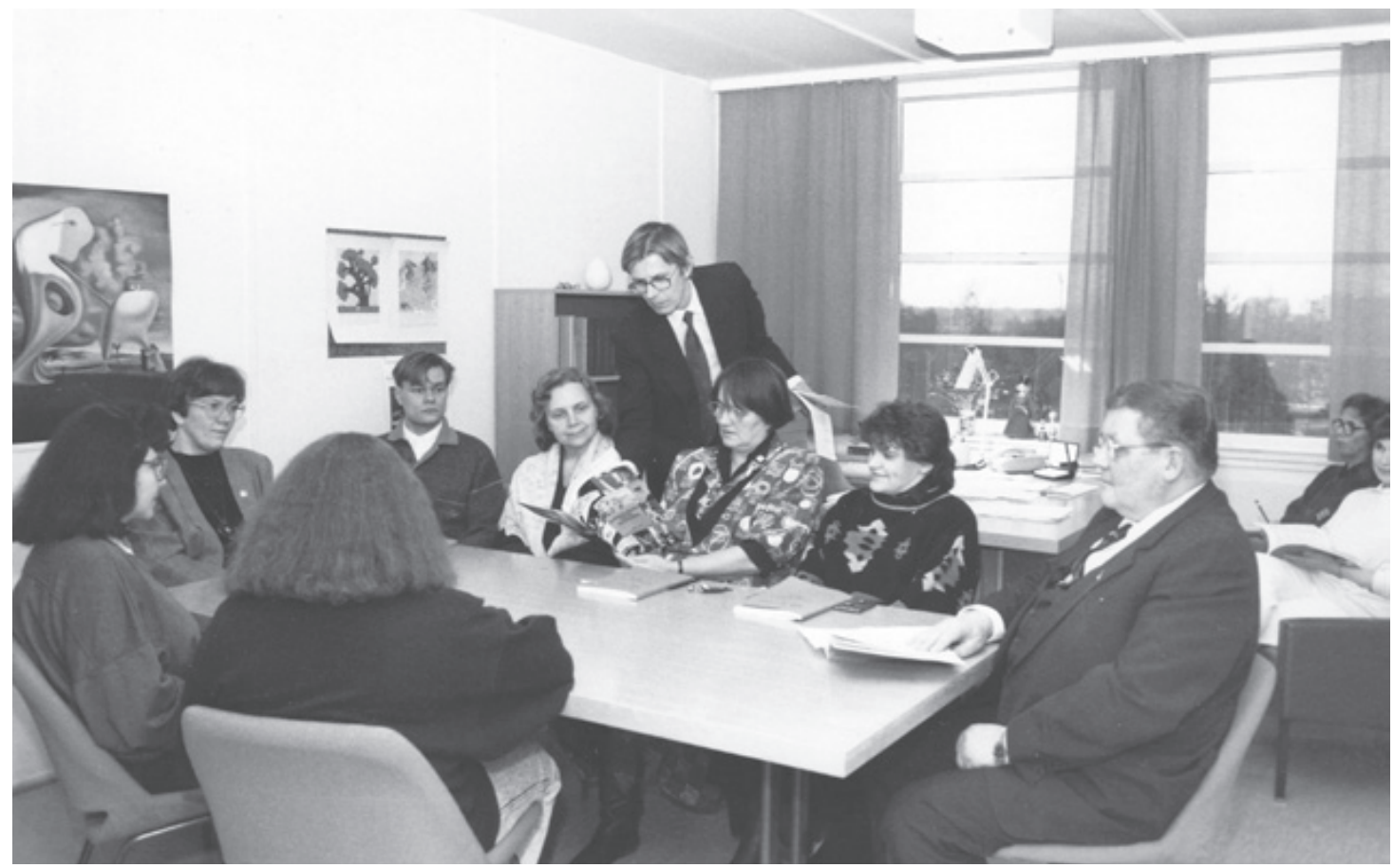

Soome ja saami keele kateedri koosolek 1988.-1989. óppeaastal. Pildil vasakult Outi Kättö, Helena Sulkala, Harri Mantila, Valve-Liivi Kingisepp, Pauli Saukkonen, Irmeli Pääkkönen, Marketta Harju-Autti, Matti Pääkkönen, Aulikki Lappalainen, Merja Karjalainen. Foto Karl Sandman 
tööle suundumist vajalikuks. Varasemate kõlakate põhjal oli teada, et eitav otsus tehti enamasti siis, kui kandidaadil oli välismaal lähisugulasi. Mul elas õde Kanadas. Ta põgenes perega 1944. aasta septembris väikese paadiga üle mere Rootsi ja liikus sealt hiljem, kui oli karta, et Rootsi annab põgenikud Nõukogude Liidule välja, Kanadasse. Olin neli korda (sic!) taotlenud võimalust õde külastada, täitnud pabereid ja maksnud riigilõivusid, kusjuures õde kinnitas iga kord oma kutses notariaalselt, et tasub kõik mu külastusega seotud kulud, aga külastusluba ma ei saanud.

Lektorikoha saamise eitavasse otsusesse suhtusin tookord kergendustundega, sest lapsed olid veel koolieas ja abikaasal oleks üksi olnud nendega raske toime tulla. Sain jätkata oma tavalist elu.

1988. aastaks oli Nõukogude Liidus toimunud poliitilisi muutusi. Arvatavasti mõjutasid Mihhail Gorbatšovi "perestroika" ja "glasnost" kõrgema hariduse ministeeriumi ja julgeolekuorganite seni ranget koostööd. Kui eesti keele kateedrist küsiti jälle uusi eesti keele lektori kandidaate Soome, ütles rõõmsameelne kateedrijuhataja professor Huno Rätsep, et kontrollime, kas "perestroika" toimib lektorikandidaatide suhtes, las Valve ja Reet täidavad vajalikud dokumendid. Oli ju teada, et mulle öeldi mõni aasta tagasi ära ja Reet Kasik ei saanud pärast esimest korda Soomes töötamist enam väljasõiduluba.

Soomes oli vabanenud kolm eesti keele lektori kohta: Helsingis, Turus ja Oulus. Kui esimeses kahes oli lektori tööleping lihtsalt lõppenud ja lektorid tagasi Eestis, siis Oulus oli olukord enneolematu. Lektor Peep Nemvalts ei naasnud enam perega Eestisse, vaid otsustas põgeneda Rootsi.

Kolmele vabale kohale täitsid dokumendid kolm kandidaati, peale minu ja Reet Kasiku veel Tiit Kukk soome-ugri keelte kateedrist. Tookordne dekaan professor Harald Peep ütles otse, et tema dekaanina annab allkirja vaid meie iseloomustustele. Olime seega olukorras, kus ülikoolist teisi kandidaate polnud. Nähtavasti ei olnud seekord ka Tallinnast kandidaate. Moskva küsis kolme ja sai Eestist kolm kandidaati, kõik parteitud. Paberiuputus oli muidugi samasugune nagu see ikka oli olnud, ainult et nüüd oli mul juba nende täitmise kogemus. Dokumendid liikusid ülikoolist Tallinna kõrg- ja keskharidusministeeriumisse ja 
sealt Moskvasse kõrgharidusministeeriumi, kuhu meid suvel instrueerimisele kutsuti. Jälle istus koos kõrge komisjon, kelle ette referent lektorikandidaadid ükshaaval kutsus. Elasin üle lõbusa hetke. Nimelt pärast seda, kui referent oli kõlava häälega hõiganud komisjonile minu ees-, isa- ja perekonnanime, leidus suure laua taga istuvas umbes 20 -liikmelises komisjonis keegi, kellele Kingisepa nimi tundus tuttavana. Ja ta päris (vene keeles muidugi), kas ma olen Viktor Kingissepa tütar. Pidin talle pettumuse valmistama, sest nimi pärineb abikaasalt, aga see ei vähendanud kogu komisjoni äratundmisrõõmu. Otsus - asute tööle Oulu ülikoolis - tuli väga väledasti. "Perestroika" toimis. Saime välisministeeriumist punased välispassid ja meid informeeriti ainult, et Helsingisse saabudes tuleb ühendust võtta NSVL saatkonnaga Tehase tänaval.

\section{Mil moel jõudsid Oulu?}

Laevaühendus Tallinna ja Helsingi vahel oli olemas juba pikemat aega. Enam polnud lektoritel kohustust lennata Soome Moskva kaudu. Minu ülelahesõit Georg Otsaga kujunes lõbusaks, sest samal laeval oli suur rühm keeleuurijaid Tartust ja Tallinnast. Oldi teel Turgu, kus pidi toimuma läänemeresoome sümpoosium. Ööbisime laevas. Teadsin, et samas laevas töötab mu onupoeg Arvi Rohumaa ja juhtumisi oli ta sel korral tööl. Ta selgitas välja, et juhtkonna sviit on vaba ja vahetasime Reedaga oma tavakajuti hoopis luksuslikuma ja avarama vastu, kus oli reisikaaslastega mõnus õhtul vestelda. Sümpoosiumile minejatele korraldati järgmisel päeval Helsingis linnaekskursioon, millest sain ka osa võtta. Väga sügava mulje jättis Sibeliuse monument. Aga mu meeleolu muutus iga tunniga kurvemaks, sest ees seisis kõigist kolleegidest lahkumine ja iseseisev tegutsemine. Käisin Tehase tänaval saatkonnas teatamas, et olen kohale jõudnud. Lukustatud väravast pääses sisse mikrofonisse kõnelemise järel. Valvur juhatas mind Valeri Korjagini juurde, kes oli tol ajal kultuuriatašee. Parteiliige pole ma kunagi olnud, võibolla sellepärast olid asjameeste jutud minuga väga lühikesed. Mulle maksti paarsada marka (täpset summat ei mäleta) sõidupileti ostmiseks Oulu, 
Korjagin andis oma visiitkaardi, soovis õnne uue töökoha puhul ja palus kontakti võtta, kui tekib probleeme. Probleeme ei tekkinud ja seepärast piirdusid minu kontaktid Vene saatkonna või konsulaadiga vaid Soome riigist lahkumise või sinna saabumise fikseerimisega. Põhja-Soome Vene saatkonna poliithariduslik töö ei ulatunud, elasin seal kui vanajumala selja taga, võtmata osa ühestki NSVL-Soome sõprusühingu korraldatud üritusest või aktsioonist. Ette ruttavalt vaid niipalju, et Raissa ja Mihhail Gorbatšovi Soome-visiidi ajal külastasid nad ka koos Tellervo ja Mauno Koivistoga Oulu tehnoloogiaküla ja ülikooli ning rektori kutsega osalesin Linnanmaal neile korraldatud vastuvõtul. Tegin sellel vastuvõtul muuseas terve filmitäie slaide, keegi ei keelanud, ikkagi vaba inimene vabal maal.

Saabusin Helsingi rongiga 30. augusti varahommikul Oulu. Nii aegsasti polnud ükski varasem lektor kohale jõudnud. Mul oli raudteejaamas vastas apulaisprofessori Matti Pääkkönen, kes viis mu kõigepealt oma koju Kuivasjärvile. Olin Mattiga korra Tallinnas kohtunud, nii et äratundmisraskusi ei olnud. Tema rõõmus aval nägu ei unune kunagi. Pääkköste kodus võtsid mind vastu kaks uhket jahikoera, kelle ülevoolav kohtumisrõõm liigutas mind kui suurt koerasõpra pisarateni. Perenaine Irmeli oli esinemas emakeeleõpetajate koolitusüritusel Joensuus, lapsed magasid veel. Matti keetis kohvi, praadis sinki ja kanamune ja me sõime. Edasi sõidutas ta mind ülikooli kantseleisse, politseijaoskonda jm asutustesse, kus uuel Oulu kodanikul tuli end meldida. Lõpuks viis ta mu Kaukovainiole, eesti keele lektorile mõeldud kolmetoalisse korterisse, kus olid olemas kõik köögitarbed ja elamiseks vajalik mööbel. Ülikool ja põhiliselt kateedri töötajad olid aastate jooksul oma külalislektoritele muretsenud kõik esialgseks toimetulekuks vajaliku. Midagi võis pärineda ka eelmiselt lektorilt. Matti muretses mulle isegi konserviavaja, kui kuulis, et mul see puudub. Erakordne vastutulelikkus, tähelepanu ja südamesoojus oli see, mis mind esimestel päevadel Oulus kohe ümbritses.

Minu töö Oulus algas õnnelikul ajal, sest ülikool sai 30 aastat vanaks ja 1. septembril peeti Linnanmaal pidulik aktus ja õnnistati sisse ülikooli uus kirik. Pääkkösed viisid mind Linnanmaale, Irmeli oli Joensuust 
tagasi ja tutvustas mind aktuse eel ja vaheajal paljudele seal viibinud ülikooli õppejõududele kui uut eesti keele lektorit. Mind silmitseti ilmse huviga, sest eelmine lektor oli otsustanud kodumaale mitte naasta. Seda sammu toonases Oulus õigeks ei peetud.

Ülikooli uues kirikus pidas avajumalateenistuse jutluse pastor Heikki Keränen, kes õnnistas kõiki jumalateenistuses osalenuid. Lahkusin sealt pühalikus meeleolus, usus ja lootuses, et kõigevägevama käsi varjab ja kaitseb mind uutel radadel, nagu ta oli hoidnud mind kogu mu senise elu.

\section{Mis aineid õpetasid?}

Hakkasin õpetama eesti keele algkursust II kursuse üliõpilastele nagu see oli kateedri tookordses õppeplaanis ette nähtud. Rühmi sai kolm. Lisaks alustasin eesti kirjanduse kursuse ja vestlusrühmaga, hiljem tulid tõlkekursus, eesti kultuurilugu, eesti keele grammatika, eesti kirjakeele ajalugu jm. Kateedris oli hiljuti (ilmselt Peep Nemvaltsi ajal) uuendatud õppeplaani ning eesti keele ja kultuuri kursusi oli kavasse võetud sellises mahus, et eesti keelt sai õppida 15 ainepunkti ulatuses kõrvalainena. Oulus töötamise ajal õpetasin kõiki kavas olnud kursusi, välja arvatud murdekursus, mida kutsusin külalislektorina lugema hea kolleegi Aino Valmeti Tartust. Tol ajal oli üldse üsna hea võimalus kutsuda külalisloenguid pidama kolleege Eestist. Kust selleks raha leiti, ei oska öelda, aga kateedrijuhataja Pauli Saukkonen toetas külaliste kutsumist ja neid käis üsna palju, minu ajal peale Aino Valmeti veel Huno Rätsep, Jaak Peebo, Mart Mäger, Reet Kasik Turust, Vaike Sarv, Toomas Help jt.

\section{Mille poolest erineb Soome tudeng Eesti omadest?}

Filoloogiaüliõpilased Oulus ja Tartus olid ealt ja väljanägemiselt kaunis sarnased. Juba kursuse sooline koosseis tuli tuttav ette: mõned noormehed suure hulga tütarlaste seas. Kohe märkasin erinevust suhtumises õppetöösse. Näiteks kui mõni tudeng käis õppetöö ajal reisil, siis tuli ta 
enne nõu pidama, kuidas puudutud tundide materjali iseseisvalt omandada, kust ja kuidas õppida. Soome tudengid olid õpingutest huvitatud, nad ei üritanud spikerdada, neid võis usaldada, nad olid ausad ja ei puudunud põhjuseta õppetöölt. Jäi mulje, et üliõpilased harjusid minu isikuga kiiresti ja meil ei tekkinud mingisuguseid konflikte. Esialgu oli liigutavalt naljakas tudengite sinatamise komme. Minu kabinetti sisenenult küsiti sinatades üht või teist lektüüri või õpetuse asjus. See tekitas üllatavalt lähedase tunde nagu perekonnaliige oleks sisse astunud. Hiljem läksin ise ka sina peale üle.

Märkasin üliõpilaste huvi Eesti vastu ja kohe, kui Tartu hakkas vabanema kinnise linna staatusest, üritasin Oulust vahetusüliõpilasi Tartu ülikooli suunata. Esimesena läks Tartusse õppima ajalootudeng Kari Alenius, seejärel soome filoloog Outi Kättö, hiljem Sakari Neuvonen ja Leena Karhumaa-Nissilä. Need olid väga tublid üliõpilased, kes ei kartnud majanduslikke raskusi, mis neid Eestis tol ajal oodata võisid. Kõigist on praeguseks saanud tublid töötegijad omal erialal ja ma olen nende üle uhke.

\section{Mis laadi ülesandeid oli sul kateedris korralisele õppetööle lisaks?}

Kateedris mul õieti muud suurt teha ei olnudki peale tudengite õpetamise. Ühel korral pidasin kateedri teadusseminaris ettekande oma uurimisvaldkonnast, eeskätt Otto Wilhelm Masingu keeletegevusest ja sõnavarast. Lisaks ettekanne eesti keele päeval. Aitasin korraldada teaduskonna töötajate ekskursiooni Eestisse ja Petseri kloostrisse. Esinesin koos Harri Mantilaga Tornio soome keele õpetajatele, kellele kateeder korraldas koolituspäeva. Olen oma kalendrisse märkinud, et olin tost päevast niivõrd väsinud, et ütlesin ära söömisest Vaakunas ja Lemmo Erendi kontserdist. “Tahan puhata!!!” on kirjas. Küllap neid etteastumisi oli ülikoolis veel, aga ka väga palju väljaspool ülikooli.

Siin rubriigis peaksin vist mainima ka osavõttu ja esinemisi eesti keele lektorite seminaridel. Esimest korda osalesin kokkusaamisel 


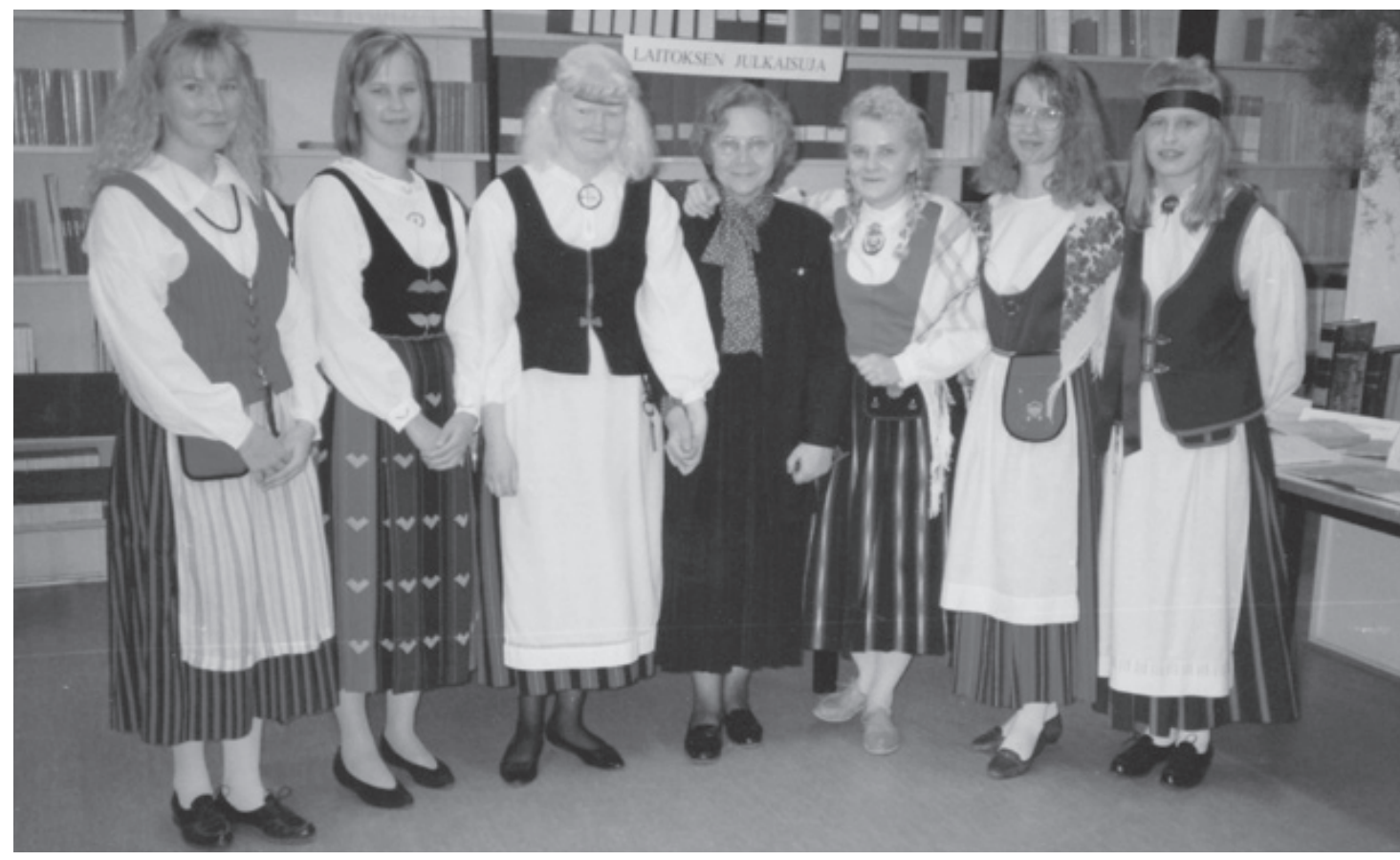

Lektor koos üliõpilastega kateedri 25. aastapäeval, keskel peapaelaga Leena Karhumaa-Nissilä

Helsingis kohe 1988. aasta oktoobris, kui Helsingi ülikool tähistas eesti keele õpetuse 50. aastapäeva. Organiseerimistöö tegi tookord suuresti ära Toivo Kuldsepp. Samasse aega jäi ka Jaak Peebo sünnipäev. Oululased andsid mulle kaasa uhke sünnipäevakingituse Jaagule - suure villasest riidest Eesti lipu, mis sobib õues kõrguvasse lipuvardasse. Olime nimelt eesti keele kateedri rahvaga olnud jaanipäeval Jaagu juures Elvas, istusime aias lõkketule ääres ja laulsime isamaalisi laule. Ja imede-ime küll - Eestimaa eri nurkadest pärit kolleegid, kes polnud kunagi varem ühistel istumistel laulnud vene ajal keelatud patriootilisi laule, oskasid neid ometi. Laulsime suure mõnuga "Eestimaa, su mehemeel, pole mitte surnud veel ..., "Meie võitluslipp sini-must-valge, aate kõrgusse näidaku teed ..., "Kaunistagem Eesti kojad kolme koduvärviga" jt. Jutustasin sellest ka Pääkköstele ja nende initsiatiivil sündiski mõte Jaagule lipp kinkida, varras oli tal olemas. Eestis tol ajal lippe veel saada polnud. Tegin seminari korraldajatele ettepaneku see lipp koosolekuruumi üles panna. Korraldajad jäid kahevahele. Leiti, et tuleb professor Seppo Suhose käest 


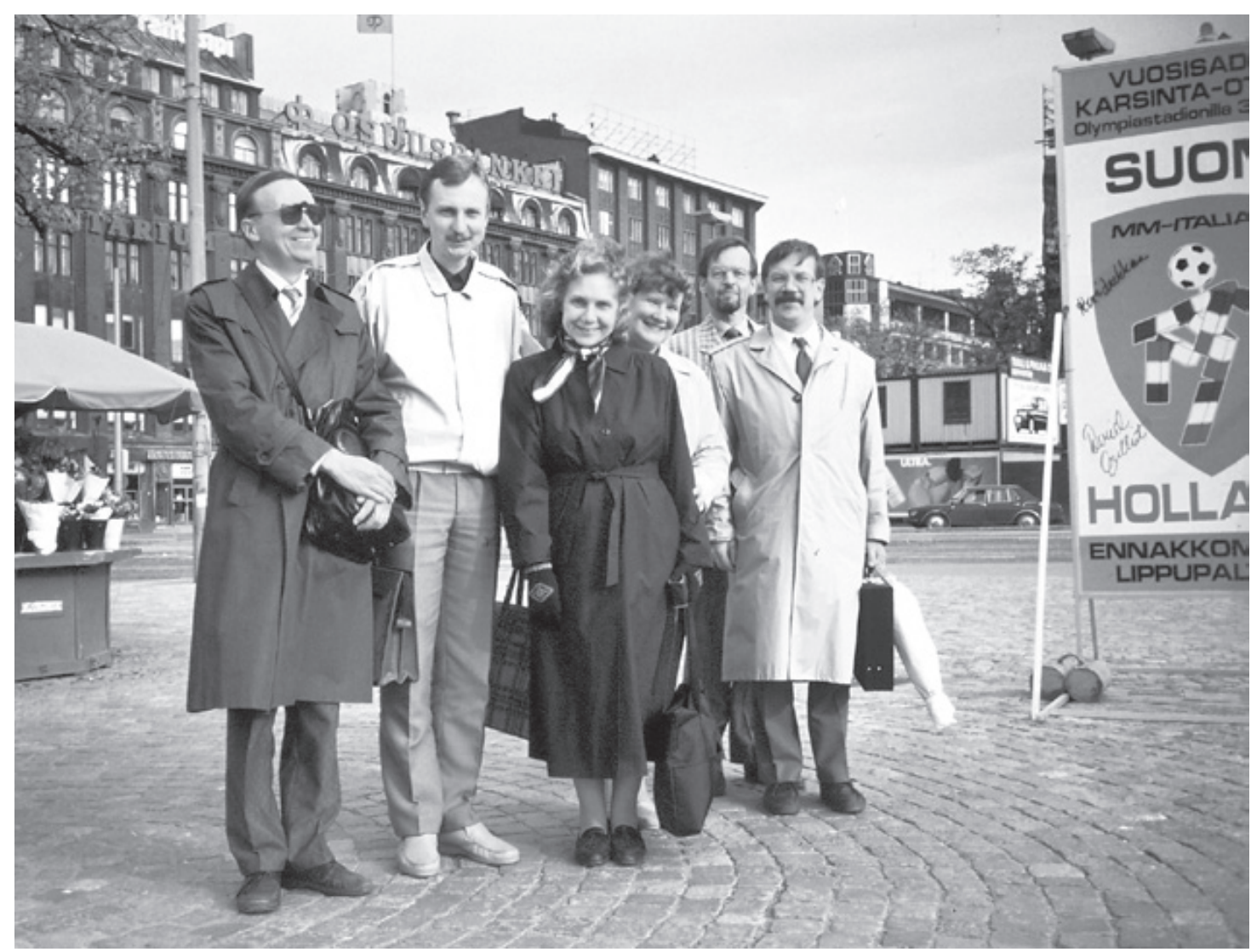

Lektorite seminar Helsingis 1989. Pildil Seppo Suhonen, Tiit Kukk, Valve-Liivi Kingisepp, Maia Väkram, Hannu Remes, Tõnu Seilenthal

luba küsida. Seppo jäi ettevaatlikuks ja soovitas lippu mitte kasutada. Oli veel selline segane aeg. Pika Hermanni torni Toompeal heisati sinimust-valge lipp ligi neli kuud hiljem, 24. veebruaril 1989.

Tookord käisin ka ekskursioonil Lope Leppälahdel, kus omal ajal kõndis Yrjö-Koskise külalisena Lydia Koidula. Kivimürakal, mille Soome härra olevat kuuldavasti naljatades Koidulale kinkinud, avati 1973. aastal Juta Eskeli valmistatud bareljeef, esimene eesti kirjanikule Soomes. Loomulikult käisime seda kivi imetlemas ja laulsime Koidula auks "Meil aiaäärne tänavas”.

Helsingis olin tagasi sama õppeaasta kevadel, kui sai teoks lektorite seminar, korraldajaiks tookordne lektor Tiit Kukk ja professor Seppo Suhonen. Oli Jakob Hurda juubeliaasta, 150 aastat sünnist, ma rääkisin Hurdast eesti keele uurijana ja kirjutasin temast ka Kaleva-lehes. Pärast 


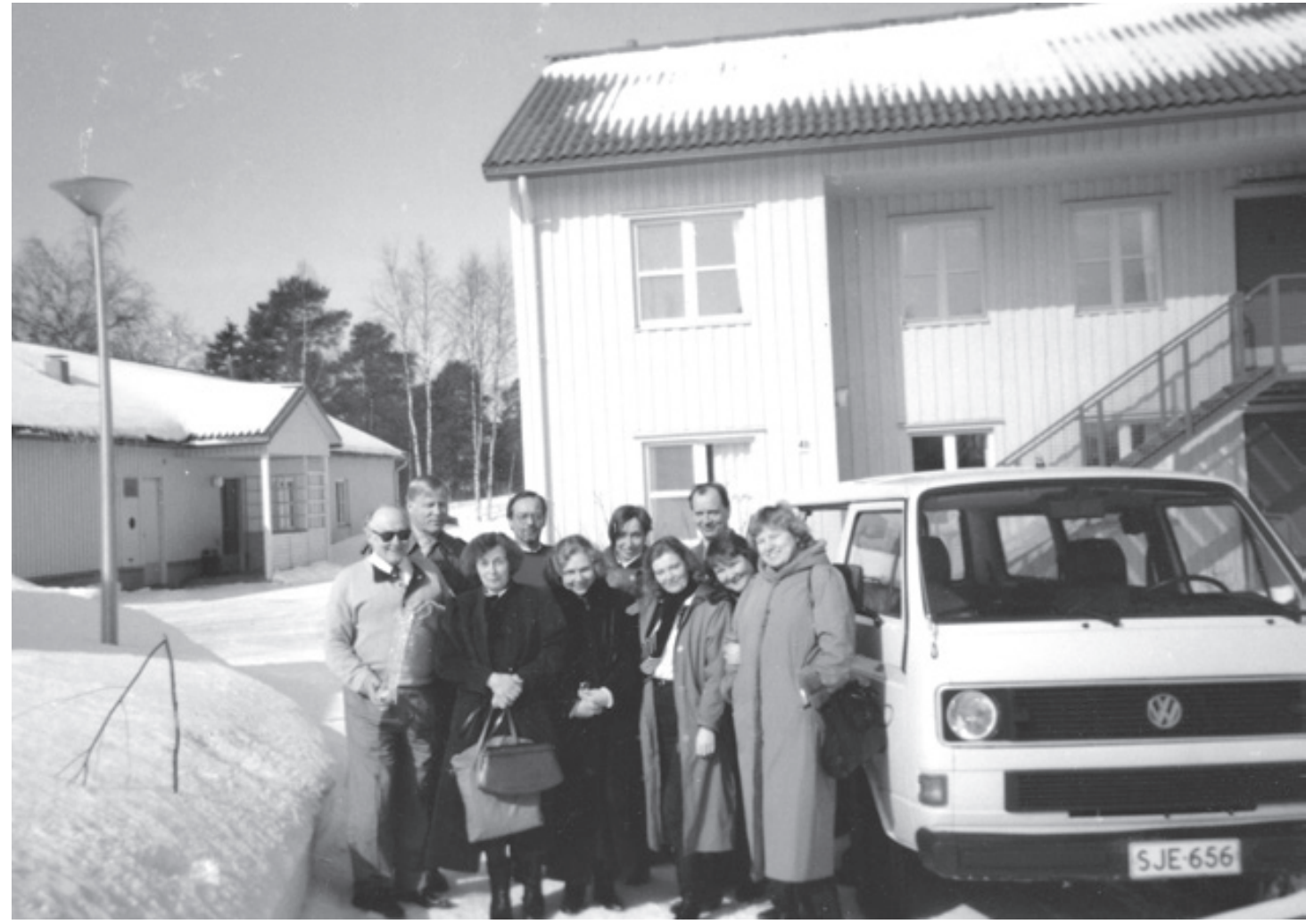

Lektorite seminar Joensuus, Mekrijärvel 1992. Pildil Kalevi Wiik, Matti Punttila, Ellen Uuspõld, Hannu Remes, Valve-Liivi Kingisepp, Birute Klaas, Ele Süvalep, Ilkka Savijärvi, Maia Väkram, Reet Kasik

seminari, mis peeti Fabiani tänaval ülikooli peamajas, veetsime meeleoluka õhtupooliku Seppo Suhose kodusel vastuvõtul.

Järgmise lektorite seminari korraldas Maia Väkram Tampere ülikoolis ja istusime koos Virroilla. Seminaridest võtsid osa ka Soome ülikoolide õppejõud, kes huvitusid eesti-soome kontrastiivsest uurimisest. Analüüsisin tookord eesti ja soome keele komitatiivi - kuivõrd erinevalt saab eesti komitatiivivorme soome keelde tõlkida. Minu jaoks viimane seminar sai teoks 1992. aastal Joensuu ülikooli juures Hannu Remesi korraldusel. Tegutsesime Mekrijärvel Ilomantsi kandis. Rääkisin eesti keele õpetamisest soomlastele ja selleks vajalikest vahenditest. Igatahes midagi kokkuvõtlikku oma senisest töökogemusest.

Mul oli rõõm osa võtta ka soome keeleteaduse päevadest. Lektoriaja sisse jäid päevad Jyväskyläs ja Joensuus, kuhu sõitsime üheskoos 
kateedrirahvaga. Samavõrd kui päevad ise on meelde jäänud sinna- ja tagasisõidud, sest kultuurihuvilised kolleegid leidsid alati midagi teelt, millest jutustada või kus peatus teha. Joensuust tulles oli võimalus külastada Eila Korpela vanematekodu, kus meid väga soojalt vastu võeti.

Hariv sündmus minu jaoks oli ka kateedri korraldatud fennistika seminar Hailuotol 1989. aasta septembris. Nägin ja kuulsin siis esimest korda soome kuulsaid keeleuurijaid Terho Itkost, Silva Kiurut, Tapani Lehtist, Heikki Leskist, Eero Kiviniemi, Heikki Paunost, Alpo Räisäst, Päivi Rintalat, Valma Yli-Vakkurit jt. Mõnda neist olin küll kunagi Eestiski kohanud, III fennougristika kongressil näiteks, aga vahetu kokkupuude puudus. Seepärast oli Hailuoto seminaril tõesti põnev olla.

Regulaarseks ülesandeks kateedris oli eestikeelse kirjanduse hankimine kateedri ja seminari raamatukogu tarvis. Pidasin läbirääkimisi Eesti vastavate kirjastuste ja väljaandjatega, tihti ostsin ise raamatud ja kateedris need kas kompenseeriti või saadeti oma väljaandeid vahetuseks. Alguses see süsteem toimis, hiljem enam mitte. Väliseestlaste väljaandeid ei õnnestunud juurde hankida. Eesti Päevaleht ja Teataja tulid regulaarselt, muud mitte. Meeldiv üllatus oli leida kabineti raamaturiiuleil kõrvuti tähestikulises järjekorras nii välis- kui ka kodueestlaste kirjandusteoseid, paljudes neist südamlikud pühendussõnad autoreilt. Näiteks "Juuditi" esmatrüki tiitellehelt võis lugeda "Laane Leenile Oru Antonilt". Eestikeelse kirjanduse väärtusliku osa oli kateeder ostnud Leeni Ploompuu-Vesterise järglastelt.

Tähtis ettevõtmine oli minu jaoks eesti keele õpetuse 25. aastapäeva tähistamine 5. mail 1992. Oli see ju nagu jumalagajätt Oulu eluga. Tegin omalt poolt kõik, mis oskasin, et see õnnestuks.

Kateedriliikmed aitasid kõvasti kaasa. Kutsusime esinema kõik endised Oulu ülikooli eesti keele lektorid. Ja nad kõik ka tulid! Ainole jäi see üldse viimaseks avalikuks esinemiseks ja vist ka Mardile. Kõik senised lektorid pidasid konverentsil ettekande. Oli see vast paraad! Kaleva-leht kirjutas sündmusest, toimetuses oli ka pidulik vastuvõtt, kus tehti ühisfoto kõigist lektoreist. Estofiilne Oulu elas sündmusele soojalt kaasa. Olid ju endised eesti keele lektorid oma kunagise tööga ülikoolis 


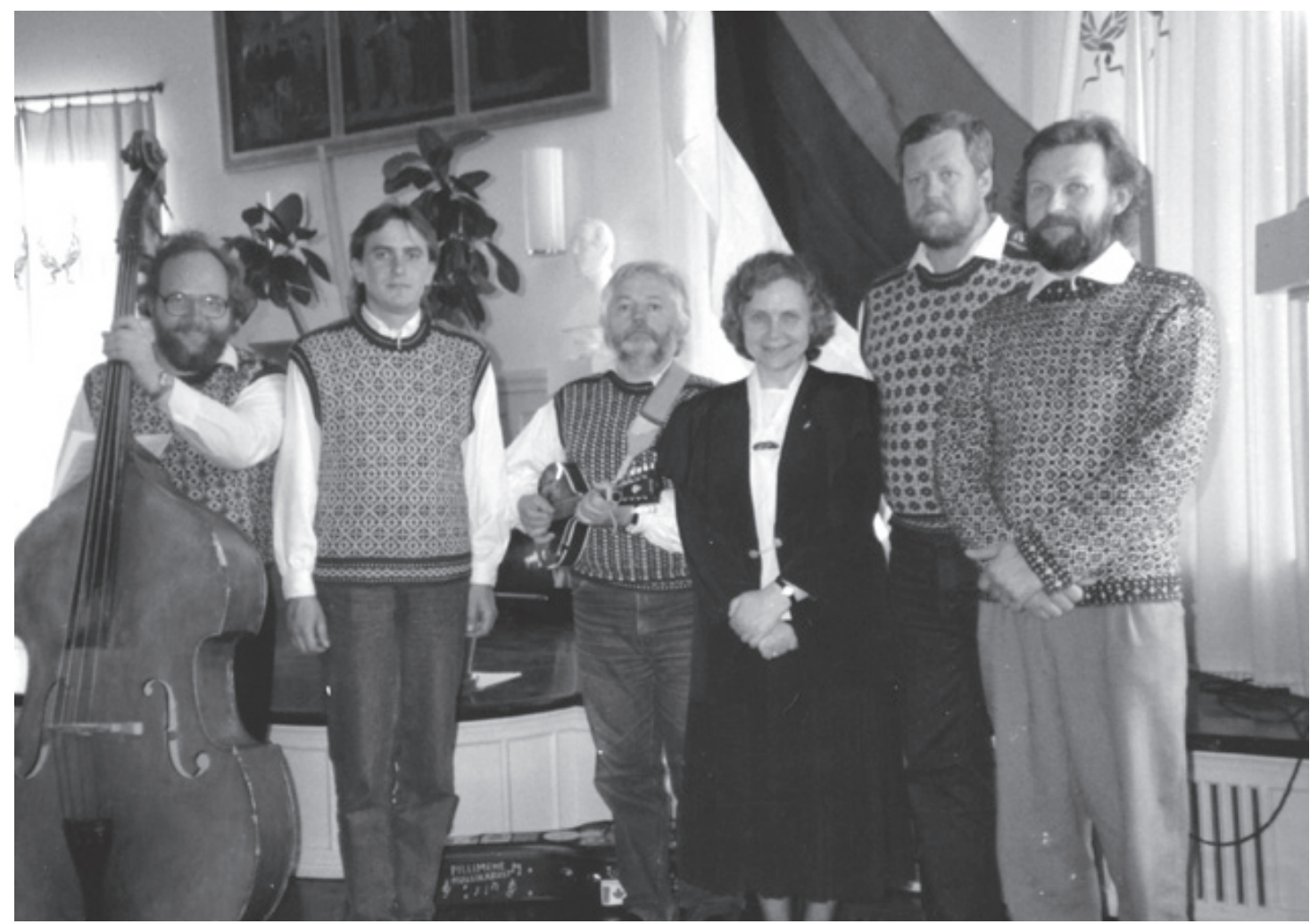

Kukerpillid pärast kontserti Oulu lütseumi saalis 1990. Foto Seppo Härkönen

kasvatanud Eesti-huvi kogu Oulu linnas. Seetõttu polnud ime, et linnavalitsus korraldas kena vastuvõtu Pehkolanlammel, olime külalised Aaro Korkeakivi kodus jm.

Plusspoolele võiksin kirjutada ka selle, et Kaljo Põllult õnnestus tellida tähtpäevaline graafiline leht, mida sai kinkida kõikidele asjaosalistele tänuks tehtu eest. Kateedrijuhataja tasus kulud. Sündmusest endast kirjutasin Kaleva-lehes ja kateedri toimetiste 35. numbris avaldasime kõigi lektorite ettekanded.

Teine palju aega ja suurt mõtlemisvaeva nõudnud ettevõtmine oli kahepäevase eesti keele ja kultuuri seminari korraldamine 1990. aasta kevadel linnaraamatukogu ruumides. Esinejatele tasumine, sõidukorraldus, majutus jm oli suveülikooli juhi Jouni Suistola mure, minu hooleks oli esinejate leidmine, asjale sisupoole andmine ja loomulikult ka ise ettekande pidamine. Ja tõepoolest, me saime Oulu esinema väga värvikad tegelased, kes esindasid Eestit ja rääkisid suurepäraselt eesti kultuurist 
tolle aja kontekstis. Kohal olid Andres Langemets, Andra ja Rein Veidemann, Jaak Kangilaski, Maimu Berg, Ingrid Rüütel, Huno Rätsep, Ain Kaalep. Lütseumi saalis andsid kontserdi Kukerpillid ja Tanel Annus tegi performance'i. Ettekanded pakkusid kuulajatele suurt huvi ja Eesti iseseisvumisprotsessis osalejad said ehk mõnevõrra jõudu juurde.

Käidi ekskursioonil Hailuoto saarel. Läänihärra Ahti Pekkala võttis valitsuse ruumides kogu selle seltskonna vastu, oldi külas Pääkköstel, Lähteenkorvade jt juures. Kaleva toimetuses peeti uhke lõpupidu, kus Ain Kaalep sünnipäevalapsena (4. juuni) jõi koos Aaroga marssalkan malja ja veedeti ülilõbusalt aega. Usun, et üritus jättis Oulu estofiilsele seltskonnale kustumatu mälestuse.

Soome ja saami keele kateedri õppejõudude koosseis oli kui hästi kokkuharjutanud sümfooniaorkester, kus olid koos erinevate pillide mängijad, kellest igaüks pakkus koosmängu õnnestumiseks ilmekaid sooloosi ja huvitavat tämbrit. Kateedri seltsielu oli väga aktiivne. Kateedriruumid paiknesid tol ajal vanas Ålstromi nahatehases Kasarmintiel. Kohvipauside ajal loeti ajalehti, sai kuulda kolleegide pereelust, linnauudistest, riigi ja linna poliitikasündmustest jm. Kuna enamik kasutas kõnekeelt ja räägiti kiiresti, ei saanud ma nende naljadest alguses aru. Otsisin sõnastikust tulutult näiteks nende suus kõlanud väljendi tuota noin tähendust. Üldse oli mu soome keele oskus nigel, kuigi olin dotsent Paula Palmeosele sooritanud omal ajal kirjaliku eksami maksimaalsele hindele, aga kõnekeelt ta meiega ei harjutanud. Suhtlus sujus siin esialgu tänu sellele, et peaaegu kõik kateedri liikmed oskasid eesti keelt, kes väga hästi, kes veidi tagasihoidlikumalt. Kõik tahtsid, et räägiksin nendega eesti keeles, soovisid oma keeleoskust edasi arendada. Pauli Saukkonen lausus mulle julgustavalt, et meie soomlased räägime siin soome keeles, eestlased eesti keeles ja me saame üksteisest väga hästi aru. Päris korrektset soome keelt ei õppinud ma ära kuni lektoritöö lõpuni, kuigi pikapeale sain ikka hakkama. Igatahes, kui läksin Lõuna-Soomesse ja seal soome keelt kasutasin, öeldi mulle, et olen omandanud mõned Oulu murdele iseloomulikud sugemed. Seda kindlasti Mattilt, sest Pääkkösed kui eriti sõbralikud kolleegid võtsid mu enne õppetöö algust oma saarele 


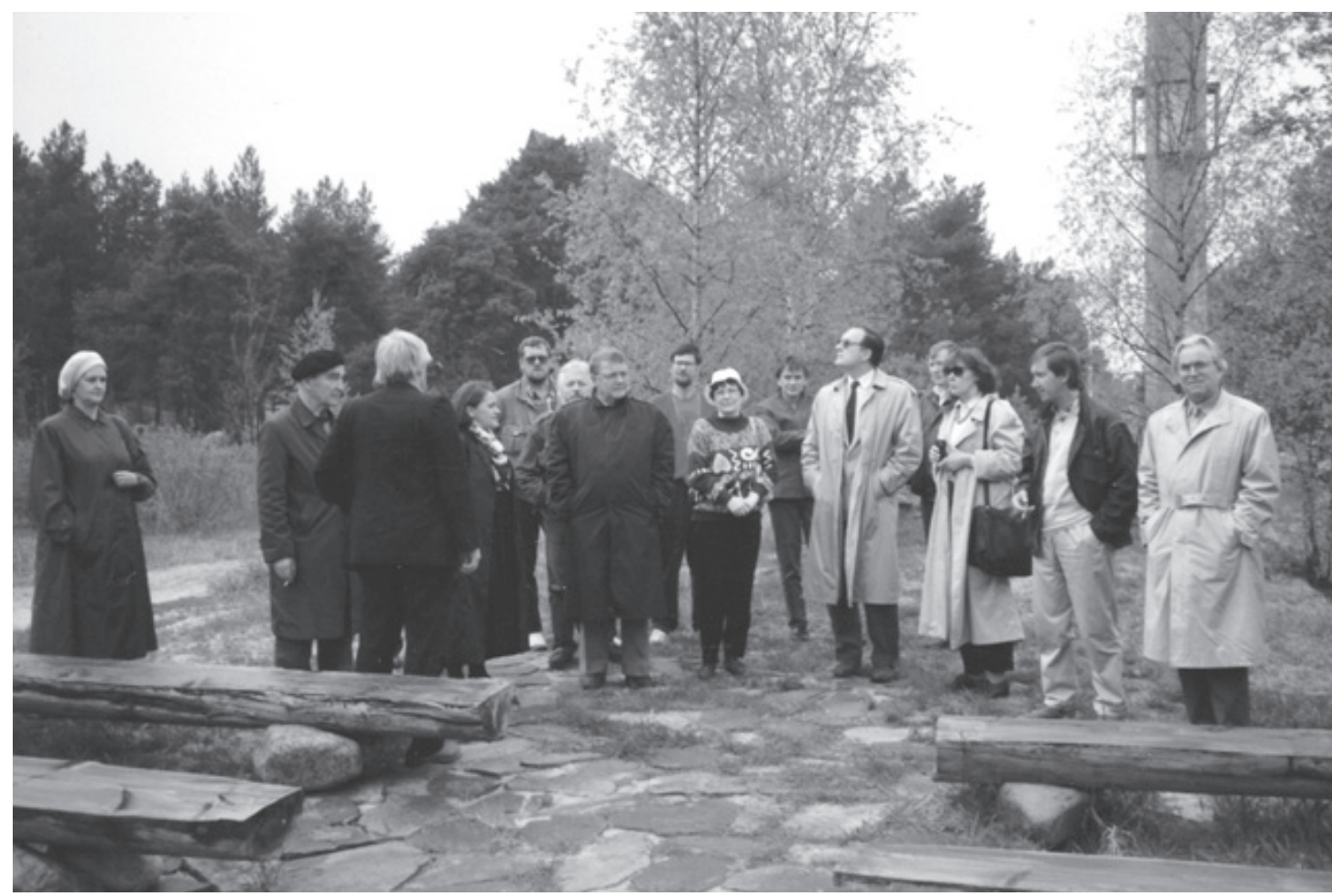

Eesti keele ja kultuuri seminarist osavõtjad Hailuoto saarel 1990.

Vasakult Ingrid Rüütel, Ain Kaalep, Marketta Harju-Autti, Matti Pääkkönen, Jaak Kangilaski, Maimu Berg, Andres Langemets, Huno Rätsep.

Foto Valve-Liivi Kingisepp

kaasa ja kuulsin kohe Soome elu alguses Matti värvikat soome keelt. Oulu murdele jäi ta truuks vist igas kõnesituatsioonis.

Kateedri õppejõudude suhted oma üliõpilastega olid väga sõbralikud, mis avaldus näiteks selleski, et kord aastas esitasid õppejõud ühisõhtul Rauhalas mingi näitemängu. Merja Karjalainen koostas teksti ja jagas osad välja. Rollidesse elati hoogsalt sisse ja näitemängu harrastati tõelise lustiga. Unustamatu mulje jättis mulle näiteks igapäevaelus soliidne härrasmees Pauli Saukkonen räbalais parvepoisina Rauhala laval.

Sama mõnuga valmistati ette kateedri jõuluõhtu kavasid, kus kõigil oli oma etteaste või esineti paarikaupa. Meelde on jäänud Harri Mantila ja ta kaaslase vaimukas paroodia sisseastumiseksamite teemal, Pauli ja ungari keele lektori Esteri esitatud karaoke "Hymyhuulet" jt. Kateedri õppejõud olid tõeliselt andekad isetegevuslased, igaüks isiksus omaette, 
seda tuleb tunnistada. Innuga tegutses ka abipersonal. Aulikki Lappalainen oli oma tööd tundva sekretäri musternäide.

Tihedat sidet peeti ajalehe Kaleva toimetusega suure Eesti-sõbra Aaro Korkeakiviga eesotsas, sekundeerisid Kaisu Mikkola, Martti Ursin, Seija Hänninen jt. Kaleva külalisteks olid paljud eesti kunstnikud, kirjanikud, kellega kohtumistest kutsuti osa võtma kateedri liikmeid. Olen seal olnud koos Hando Runneli, Endel Mallese, August Eelmäe, Jüri Arraku, Herald Eelma, Kaljo Põllu, Raimo Pullati, Heino Kiige, Merike Männi ja teistega, kelle teoseid kirjastus Pohjoinen avaldas ja esitles või kelle näitusi parajasti avati. Kogunes ju Kaisu Mikkola initsiatiivil Kalevale suurepärane eesti kunstikogu ja Berit Tähtinen kandis hoolt, et igal aastal ilmuks kirjastuses Pohjoinen üks eesti kirjaniku teos.

Ma ei unusta esimest kokkupuudet kultuuritoimetaja Kaisu Mikkolaga, kes tuli mind mu kabinetis intervjueerima ja ilmutas taas omamoodi huvi mu perekonnanime vastu. Kaisu soovis intervjuud minu esimesel saabumispäeval, aga Matti andis nõu natuke viivitada, soovitas veidi olukorraga kohaneda ja alles siis ajakirjanik jutule võtta. Vestlus möödus sõbralikus õhkkonnas, aga ma nägin, et ajakirjanikku vaevas üks probleem - minu perekonnanimi. Ta viivitas ja viivitas, aga lõpuks küsis ikkagi otse, kas ma olen Viktor Kingissepa sugulane. Saanud teada, et see nii ei ole, lahkus ajakirjanik kergendatud tundega ja muuseas mainis seda ka mind tutvustavas artiklis Kalevas. Küllap kartsid oululased, et Moskva on neile pärast Nemvaltsi põgenemist saatnud tööle ühe tõelise kommunisti, revolutsioonilise karastusega lektori. Ma ei söandanud kohe alguses oma isiklikku elulugu võõrastele üksikasjalikult seletada, aja jooksul saadi teada, et vaid õnneliku juhuse läbi pääsesin 1949. aasta märtsiküüditamisest, kui mu vanemad olid kulakuks tehtud ja kogu pere Siberisse saadeti, et minu üks õde arreteeriti metsavendade toetamise pärast 1948. aastal ja ta sai karistuseks $25+5$ aastat, et mu vend arreteeriti kui rahvavaenlane kohe pärast merekooli lõpetamist, et mu teisel õel õnnestus koos perega 1944. aastal Rootsi põgeneda jne. Kuulusin perekonda, kelle juured kiskus nõukogude võim kodupaigast välja ja kelle tulevik üritati hävitada. Vaid isikliku vapruse, sihikindluse ning 
sugulaste abiga sain hariduse ja Peet-Hennuga abielludes Kingisepa nime, auväärse nime, sest abikaasa ema oli Tartu ülikooli füsioloogiaprofessor ja isa esimene eesti soost farmakoloogiaprofessor ning mõlemad vastavate kateedrite juhatajad. Kommunistliku ideoloogiaga polnud sellel perekonnal vähimatki sidet. Mu ämma ema ja õde põgenesid 1944. aastal Saksamaale, sealt Rootsi ning hiljem edasi Kanadasse.

Küllap sai minu suhtumine nõukogude võimu peagi teatavaks, kogesin kogu Oulus töötamise aja väga südamlikku suhtumist ja sõbralikku tähelepanu kõikjal, kus puutusin kokku kohalike inimestega olgu Kaleva toimetuses, linnaraamatukogus, suvekursustel, aga eriti ümbruskonna rahvaülikoolides.

\section{Millega tegelesid väljaspool ülikooli?}

Võin liialdamata öelda, et töö väljaspool ülikooli andis mulle sama suure koormuse kui ülikoolis, mõnes mõttes suuremagi. Sattusin Oulus tööle ju väga erilisel ajal. Eestis oli käivitunud iseseisvumisliikumine. 1988. aasta aprillis, muinsuskaitsepäevadel, toodi välja rahvusvärvid sinimust-valge. Juunis toimusid öölaulupeod, septembris ligi kolmandiku eestlaskonnast Tallinna lauluväljakule koondanud üritus "Eestimaa laul". Oli alanud laulev revolutsioon. Soomlased elasid eestlaste iseseisvumispüüetele väga soojalt ja elavalt kaasa. Küllap see oli üheks põhjuseks, miks kasvas rahvaülikoolides huvi eesti keele õppimise vastu. Minult oodati peale keeleteadmiste üldse teateid Eestis toimuvast. Paljud varasemad eesti keele lektorid olid õpetanud eesti keelt Oulu Työväenopistos. Linnas oli kenake hulk inimesi, kes oskasid hästi eesti keelt. Aga uusi huvilisi tuli ikka juurde. Jätkasin tööd kahe rühmaga.

Suur oli minu üllatus, kui 1989. aasta kevadsemestril kutsuti mind eesti keelt õpetama Kempele rahvaülikooli. Lütseumi klassiruum oli rahvast täis, kohale oli tuldud perekonniti, nii et alustajaid oli ühtekokku üle kolmekümne. Kempele noortekoor valmistus Seppo Härköse juhtimisel kontserdireisiks Tartusse ja suure sõidu ettevalmistuste hulka kuulus ka keeleõpe. Härköste pere algatas Kempele ja Tartu vahelised 


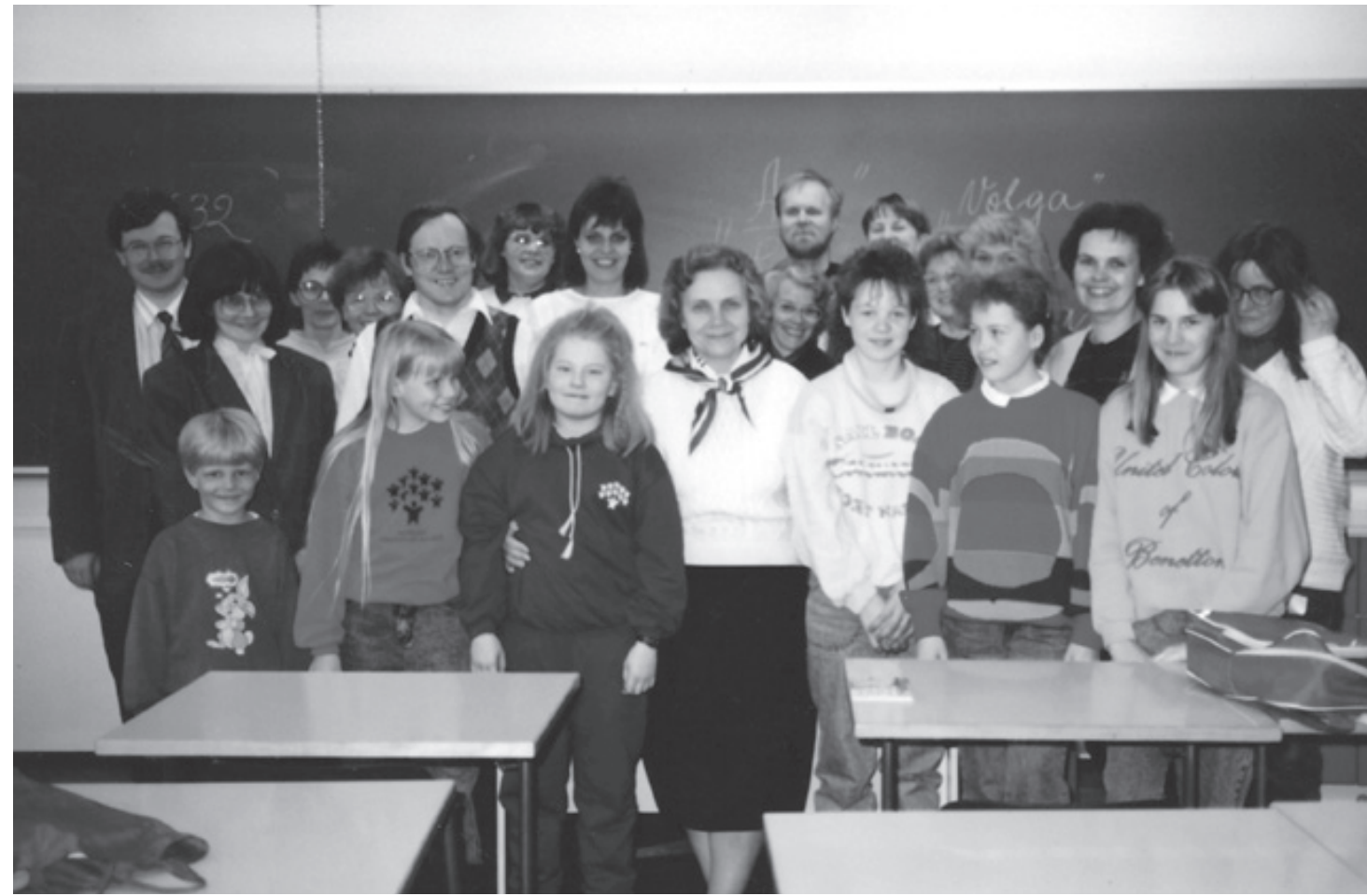

Lektor koos eesti keele huvilistega Kempele rahvaülikoolis kevadel 1989

kultuurikontaktid, eeskätt kooride vastastikused külaskäigud, seejärel perede sõprussuhted, eesti kunsti näitused, Põhjamaa Eesti Seltsi jpm. Nende kodus käisid sajad eestlased. Maisast ja Seppost said minu usinad ja andekad eesti keele õpilased, kes teevad oma hea keeleoskusega õpetajale au iga kord, kui nad Eestisse saabuvad. Nendega kohtumine kosutab ja ma rõõmustan südamest, kui nad Tartus käies mu kodu külastavad. On inimesi, kes jäävad kalleiks elupäevade lõpuni.

Teine eesti keele õppijate huviring kasvas välja Jäälis, kus kujunes oluliseks eestvedajaks Ojalehto pere. Töötasin ühe õppeaasta sealses rahvaülikoolis. Jäälisse minek oli lihtne, sest Oulust viis sinna buss, aga tagasitulek Jäälist oli väga ebameeldiv. Nimelt sain õhtul pärast tunni lõppu tagasi vaid Kuusamo-Oulu kaugliinibussiga, mida tuli oodata kiirtee ääres. Talvises tuisus vurasid must täiskiirusel mööda suured metsaveo- ja muud masinad. Vahel tundsin end lausa ohus olevana ja hingasin kergendatult, kui hoomasin kaugelt tulevat bussi, mis minu käeviipele reageerides peatus ja mind Oulu sõidutas. 


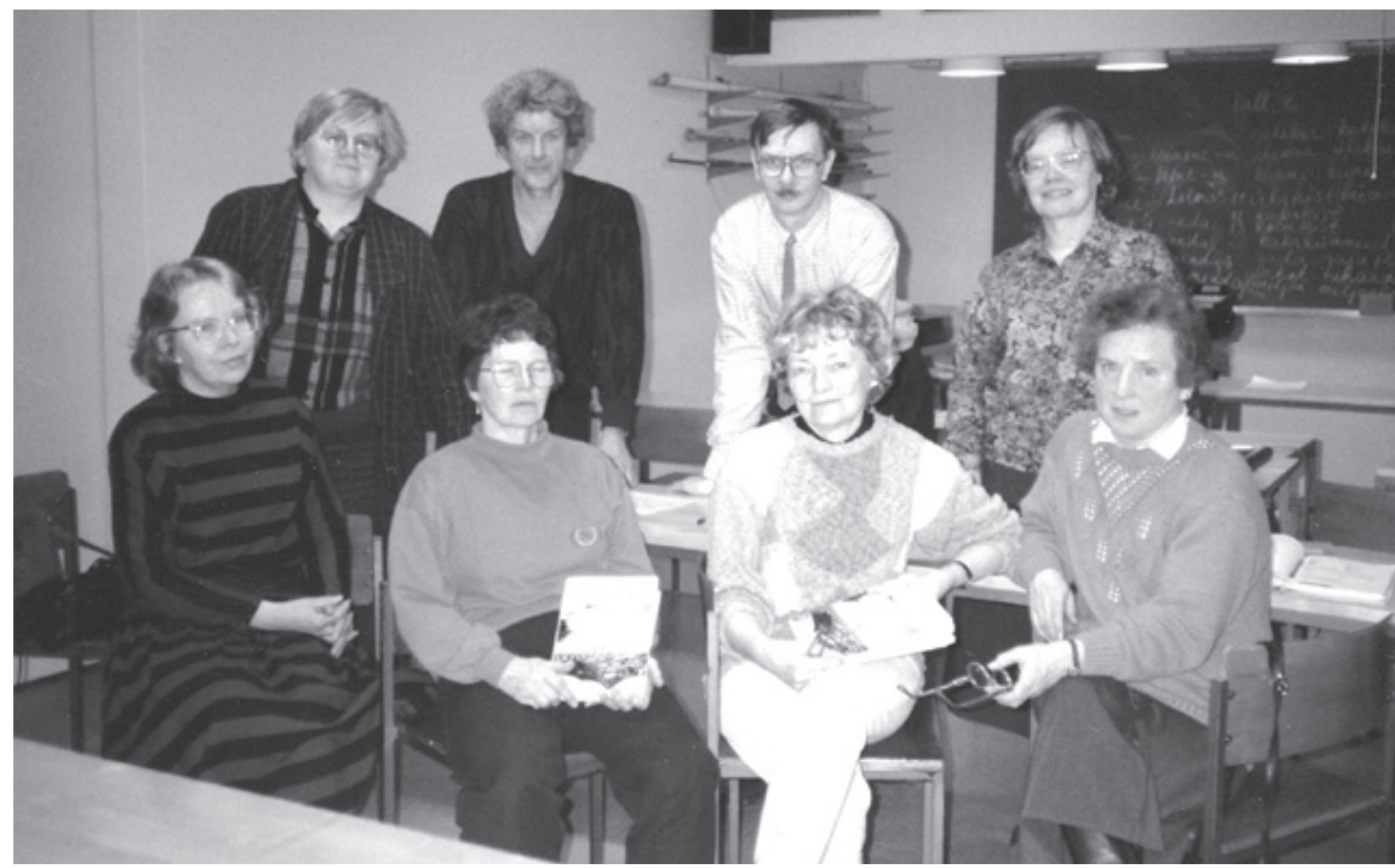

Kemi eesti keele õpperühm aprillis 1990, vasakul seisab Vappu Kraatari, oppetöö initsiaator ja korraldaja. Foto Valve-Liivi Kingisepp

Kolmas huviliste ring tekkis Kemis. Kuuldavasti olevat sealses rahvaülikoolis varemgi tahetud avada eesti keele kursust, aga ükski eesti keele lektoreist polevat nõustunud sinna regulaarselt sõitma. Mina võtsin pakkumise vastu ja sõitsin kaks korda kuus reede õhtuti Kemisse 4 tundi jutti eesti keelt õpetama. Leidsin eest erakordselt toredad inimesed ja asjahuvilised, nii et ma jäingi sinna sõitma, kuni lõpetasin lektoritöö Oulus. Rahvaülikooli juht Vappu Kraatari, kes mu Kemisse kutsus, oli mul iga kord oma väikese Suzukiga raudteejaamas vastas, lükkas autoklaasid jääst puhtaks (olime ju kaugel põhjas), sõidutas mind oma töökohale, pakkus kuuma kohvi ja head kohvikõrvast ja siis läksime koos tundi. Ja nii algasid kolme õppeaasta jooksul kõik minu Kemis peetud eesti keele tunnid. Tagasi pääsesin kesklinnast bussiga ja Vappu jälgis, et ma bussist maha ei jääks. Harva leidub sellise südameharidusega inimesi, kes tahavad ja oskavad mõtestada endale võetud kohustusi teise inimese heaolust lähtuvalt. Vappu oli ja on üks selliseid. 
Ka eesti keele õpetus arenes Kemis jõudsalt, sest õppijad olid enamasti kõrgharidusega inimesed, paljud neist kooliõpetajad, insenerid. Minu õppemeetodid olid tol ajal küll väga traditsioonilised, kui vähegi enesekriitiline olla, aga minu õpetust võeti meelsasti sellisenagi vastu ja me jõudsime alg-, järg- ja vestluskursusest tõlkekursuseni välja. Proovisime jõudu värskelt Loomingus ilmunud Mihkel Muti looga "raisakassist". Jah, tõesti toredad, mingi erilise auraga olid Kemi eesti keele õppijad, kellelt saan tervituskaarte reisidelt ja pühadesoove siiani. Kui sealse rühma kingitud väljaannet "Tuuppa kattoon" aeg-ajalt sirvin, meenuvad need toredad inimesed taas ja taas.

Esinemisi väljapool ülikooli oli üsna palju. Meelde tulevad Taivalkoski kool ja imearmas väike Aittokylä kool, kus olin 5. mail 1989. Mäletan, et õpetasin lastele kaks eesti laulu: "Vares vaga linnukene" ja "Uhti, uhti uhkesti”.

Lisada tuleb veel, et õpetasin kolmel korral ka suveülikoolis. Esimene suveülikool sai teoks Lapi kõrgkooli korraldusel Tornio Kivirannas 1990. aasta juunis. Küll see oli ilus aeg! Ja need õppijad! Neli tundi järjest! Et nad suudaksid virged olla ja õpetust vastu võtta, leppisid nad kokku, et kordamööda toob üks õppijaist kaasa kohvitermose ja midagi kohvi kõrvale. Kaunid sööginõud olid kohapeal olemas, sest õppetöö toimus vanas koduperenaiste kooli ruumides Peräpohjolas. Iga päevaga läks söögipaus aina uhkemaks, sest keegi ei tahtnud teistest kehvem olla. Mulle tundus, et nad natuke nagu võistlesid. Ja mina sõin mõnuga ning kurtsin, et lähen aina priskemaks. Siis toodi mulle jalgratas, et ma saaksin Tornio ümbruses ringi sõita. Ja sealne ümbrus oli tõesti kaunis Ala-Tornio kirik ja kirikaed, Tornio jõe kaldad, Kukkola kose vetevood, õhtuti nautisin loojuva juunipäikese värve jõe kaldal istudes, imetlesin kaunist Soomemaad ja põhjala valgeid öid. Ka Tornio suvekoolist osavõtjad ei unune mul niipea, sest nad kinkisid mulle padja ja voodipesu, et ma ka magama heites nende peale mõtleksin. Nii see tihti juhtubki. Meri Kailaga, ühe tookordse keeleõppija ja hilisema paljude unustamatute koduste vastuvõttude korraldajaga, käisime pärast suvekursust toredal Rovaniemi-reisil. Ta viis mu vaatama imetabast loodusnähtust 
Hiidenkirnusid, pidasime piknikku Pöykköläs ja vaatasime Ounasvaara pilvepiirilt alla üle õitsva Soomemaa.

Teine suvekool oli Oulus, kolmas Raahel, kus sain jälle kokku väga toredate inimestega, teiste seas Raahe noortekoori dirigendiga, kelle palvel tõlkisin soome vanu meremehelaule eesti keelde, sest koor valmistus kontserdireisiks Eestisse. Õppisin tundma Raahe linna peamisi vaatamisväärsusi, meremuuseumi, kiriklat jm.

\section{Mida huvitavat kogesid Soomes?}

Eelnevast selgus, kuhu minu aeg Oulus töötades kadus. Tuleb lisada seda, et enamik mu õpilasist soovis mind näha ka oma kodus. Suur osa mu vabast ajast kulus suhtlemisele. Olen rehkendanud, et Oulu-aastail oli mul rõõm ja võimalus külastada 43 soomlase kodu, paljusid korduvalt. Kateedri liikmeid pole siin põhjust nimetadagi, sest nende juures käisin ma sageli ja külastamata ei jäänud peaaegu keegi. Sulkalate ja Pääkköste pool tundsid ju kõik lektorid end kui omas kodus. Mõnd külaskäiku tahaksin siin meenutada.

Olin juba natuke aega Oulus töötanud, kui Tauno Lähteenkorva kaudu saabus mulle kutse külastada Tytti Isohookana-Asunmaad tema kaunis kodus Haukipudal, põhjus - läänihärra Ahti Pekkala tahab minuga tutvuda. Keegi oli veel kutsutud, aga ma ei mäleta, kes, sest ma ei tundnud siis veel oululasi. Sõime perenaise küpsetatud maitsvat lõhepirukat, midagi magusat ja järgnes jutuajamine läänihärraga. Kartsin seda jutuajamist mitmel põhjusel. Esiteks sellepärast, et läänihärra on Soomes väga kõrge ametiisik, teiseks ei teadnud ma läänihärra poliitilistest vaadetest midagi ja lisaks kartsin teha soome keeles vesteldes vigu. Aga olukord kujunes minu jaoks väga soodsaks, sest läänihärra osutus jutukaks härrasmeheks, kes tundis hästi soomlaste ja üldse soomeugrilaste esiajalugu ja demonstreeris mulle oma teadmisi. Mulle tundus, et ta oli isegi eelnevalt mõnd vastavat erialateost värskelt lugenud. Kuulaja roll mulle sobis. Mõne mõtte sain ka vahele poetada ja nii möödus õhtu minu jaoks õnnelikult. Tauno sõidutas mu koju Kaukovainiole ja hiljem 
kuulsin "Kobrulehelt", et läänihärra avaldanud heameelt - Oulu ülikool on saanud endale pädeva eesti keele lektori.

Läänihärraga saime kokku veel. Läänivalitsuse sekretäri Ritva Parviaise vahendusel sain kutse tulla tõlgiks Saaremaa maavanema ja abimaavanema ning nende prouadele korraldatud vastuvõtule. Neile tehti linnaekskursioon, käidi tehnoloogiakülas ja Nallikaril lõunat söömas, Muhoksel ja Rokual. See vastuvõtt oli huvitav mullegi ja keeldusin tõlgitasust, aga läänihärra käskis saata arve kõige kõrgema taksi järgi. Kui Gorbatšov külastas Oulu ülikooli Linnanmaal, oli vastuvõtjate hulgas ka läänihärra. Pärast kõnesid otsis ta mu üles, et tutvustada mulle üht eestlast. Ja selleks eestlaseks osutus Vaino Väljas. Istusime Väljasega lõunasöögi ajal ühes lauas ja ajasime juttu. Ta tundis sõbralikult huvi, kuidas mu töö edeneb ja soovis kõike head edaspidiseks. Mäletan seda põgusat kohtumist soojade tunnetega.

Oulu-aastaisse jääb mu esimene reis Rootsi kuningriiki 1990. aasta mais. Olin siis veel monstrumliidu kodanik, kellel polnud ametlikku õigust Soomest kuhugi mujale kui koju minna. Küsisin isegi saatkonnast luba, aga ei saanud seda. Teaduskond korraldas sõidu Umeåsse tutvumaks sealse ülikooliga. Otsustasin riskida ja läksin kateedrirahvaga kaasa. Oli hästi huvitav reis! Sõitsime Vaasast laevaga üle mere ja tagasi, juba söögid Rootsi laevas jätsid kõigile kustumatu mulje. Isegi palju heaga harjunud soomlased kinnitasid, et rootslaste seisova pöytä ületab suuresti soomlaste omi. Peale ülikooliga tutvumise käisime Umeå vabaõhumuuseumis ja sõime lõunat kaunis kartanos, käisime linnas ringi ja Helena Sulkala viis mu sealse ülikooli lapi keele professori koju. Professor ise oli kusagil ära, aga meid võõrustas tema väga armas proua.

Linnas liikudes mõtlesin, mida osta mälestuseks esimeselt Rootsireisilt, ja otsustasin Kosta Boda klaaskausi kasuks, kus peal Rootsimaa eri maakondade sümbolid. Nüüd on mu kodus ese, mis kannab häid mälestusi.

Ka esimese Norra-reisi tegin Oulu-aastail. Ja jällegi nii, et polnud mul mingit ametlikku luba seda teha. Ruska-aegse Lapimaa-sõidu otsaga Norrasse Põhja-Jäämere äärde välja korraldasid mulle ja Reedale 
Pääkkösed. Peatusime Vuontispirtis, läbisime Enontekio, jõudsime Altasse, uurisime sealseid kaljujooniseid ja tulime Karasjoe kaudu Utsjoele, kus elas lapi keele professor Pekka Sammallahti oma abikaasaga. Nende juures olimegi ööd. Neljapäevase sõiduga nägime väga palju huvitavat: imelises värvikülluses Lapimaad ja Norra fjordide kõrgeid tumedaid kaljusid. Pesime nägu külmas Põhja-Jäämere vees.

Toredaid reise Soomemaal oli mitmeid. Emakeeleõpetaja Maina Kivioja korraldas mulle 1989. aasta mai algupoolel uhke sõidu LääneSoome. Olime Haapavedel, Raahe vanas puulinnas, Ylivieskas, Kalajoel Maina õe rebasekasvanduses, Kokkolas, Seinäjoel, mille staadionil jälgisime eesti-soome rahvapidu, Maina tädi juures Peräseinäjoel, kus elasime teleka vahendusel meeleolukalt kaasa parajasti toimuvale Eurovisiooni lauluvõistlusele. Mäletan, et Soome esindaja, mitte kõige noorem laulja, sai 6. koha.

Teine vapper emakeeleõpetaja Tuula Uusi-Hallila korraldas mulle sõidu Ida-Soome. Läbisime Kajaani, Kuhmo, Nurmekse ja ööbisime Lieksas. Imetlesime Ruuna koski ja sõitsime praamiga üle Pielise järve Kolisse. On see vast imetlusväärne koht! Kui kõrgelt kaljult üle kuuselatvade järvele vaadata, hakkab kõrvus helisema Sibeliuse sümfooniline muusika. Kuuldavasti saanud ta just IV sümfoonia algtõuke Kolil viibides. Meie sõit Tuulaga jätkus Savonlinnani, kus kohtusime Irmeli ja ta tütre Saaraga. Käisime muidugi Punkaharjul. Irmeli lausus seal Runebergi luuleridu rannalta täältä palasen maat ihanaista isien sa näet nuorukainen. Käisime Valamo kloostris, Varkauksel ja suundusime kahe autoga Irmeli ja Matti kodusaare poole Leppävirta kanti. Matti tuli paadiga oma perele vastu ja meie Tuulaga suundusime Kuopio kaudu Oulu poole. Sain küll aru, et sõit kurnas ja väsitas Tuulat, aga ta pidas autoroolis vapralt vastu ja me jõudsime õnnelikult pärale. Hiljem sain Tuulalt sünnipäevakingiks Iittala klaasist tordialuse, millel kuuski meenutav ornament. Ja iga kord, kui seda kasutan, meenub mulle vapper ja alati heatahtlik Tuula ning imeline Koli.

Soomlaste korraldatud sõite tegin Soomemaal veel palju-palju, sest õnnestus ju külla kutsuda ka oma pere liikmeid ja kõiki meid sõidutati 
mitmele poole. Sõidutajaiks muidugi Pääkkösed, kelle külalislahkus oli piiritu, samuti Tauno, Jouko, Helena, Tuula, Itkosed, Pentti Kela jt. Peresõidud jätan siin nimetamata, aga olen südames piiritult tänulik kõigile headele oululastele, kes ei pidanud paljuks vaeva, et näidata eestlastele oma kaunist isamaad.

Oulu pakkus üsna huvitavat kultuurielu. Kui vähegi vaba õhtupoolik oli, käisin Madetoja saalis kontsertidel, eriti meeldisid mulle sümfooniakontserdid. Peale Oulu linnaorkestri sai seal kuulata ka külalisorkestreid, häid instrumentaalsoliste. Mitmel korral nägin ja kuulsin dirigeerimas kadunud Peeter Liljed. Kord oli solistiks Kalle Randalu, kes mängis vapustavalt hästi Béla Bartóki teist klaverikontserti ja peast! Tookord dirigeeriski Lilje. Paavo Järvi käis korra dirigeerimas. Huvitavaid muusikaisiksusi sain kuulata palju.

Ooperiteatri külaline sain ka võimalust mööda olla. Kord laulis seal külalisena Teo Maiste.

Ja muidugi kunstinäitused! Osalesin paljudel Kaleva galeriis avatavatel kunstinäitustel, sest neil oli kombeks mind sinna kutsuda. Tore oli Jüri Arraku näitus, samuti Kaljo Põllu näitus linnaraamatukogus, millele koostasin kava, Evald Okase näitus, paljude Oulu kunstnike väljapanekud.

Kui Oulu kultuurielu kohta midagi üldistavat öelda, siis tunnistan, et sealne kontserdi- ja teatrielu oli heal järjel, aga midagi täiesti üllatavat ma ei leidnud, sest ka Eesti kontserdi- ja teatrielu oli heal järjel. Mis mind sügavalt liigutas, oli Oulu ja üldse Põhja-Soome kirikuelu, sealse kirikuelu kultuuritase. Nõukogude aeg oli Eesti kirikud peaaegu maatasa teinud ja seepärast paistis erinevus nii silma. Olen ju ristitud ja leeris käinud inimene, minu süda oli avali jumalasõnale, mida PõhjaSoome kirikutes kuulda sain, ja see andis jõudu töötada oma võimete piiril, pühenduda mulle usaldatud ülesandeile täie jõuga, mõeldes samas kodustele ja kõigile lähedastele, talveõhtutel põhjala täistaeva kaudu neile tervitusi läkitades. Polnud ju siis veel ei mobiiltelefone ega e-postindust. Eesti Raadiot kuulsin varahommikuti läbi hirmsa ragina, Eesti Televisioon Põhja-Soome ei ulatunud, Eesti ajalehed tulid 
vähemalt 10-päevase hilinemisega. Pauli hea inimesena lubas mul kodustega sidepidamiseks kasutada kateedri telefoni. Ja sellest oli mulle palju abi.

\section{Missuguseiks kujunesid töösuhted kolleegidega, linnarahvaga?}

Üldine atmosfäär oli minu tööaja Oulus meeliülendav. Kohe esimestel töönädalatel kogesin väljaspool ülikooli suurt huvi ja heatahtlikkust eestlaste vastu, ülikoolist ei maksa rääkidagi. Nimelt sain Maija-Liisa Härköselt kaardi kutsega tulla Kempelesse Tartu koori Kurekell kontserdile ja nendega koos bussireisile Torniosse ja Rovaniemile. Võtsin kutse vastu. Kempelesse oli jõudnud kaks bussitäit eestlasi, laululapsi Lennart Jõela, Anu Köbase, Undel Koka ja Verni Loodmaa juhtimisel, kaasas ka Age Raa Eesti Raadiost. Kontserdist kujunes kahe sugulasrahva sõpruse hiigeldemonstratsioon. Kontserdimaja oli rahvast puupüsti täis, soomlased nutsid püsti seistes, kui koor laulis "Finlandiast" pärit soomluse hümni "Oi nouse, Suomi”. Lapsed majutati Kempele peredesse, kus nad külvati üle kõige vajalikuga, mis tol ajal Eestis puudus. Rovaniemi lähedal Jõuluvanamaal sõitis Eesti bussidest mööda tookordne APN-i korrespondent Enn Anupõld ja ei uskunud oma silmi - eestlased bussidega kaugel põhjas.

Selle kontserdimatkaga, mis Härköste initsiatiivil ellu kutsuti ja igati korda läks, panid nad aluse edaspidistele paljudele toredatele eestisoome kultuuriüritustele, mis kuuldavasti kestavad praegugi.

"Pohjoinen estofiilia" oli juba minu eelkäijate poolt tekitatud ja mina sain seda tööd vaid jätkata. Kui varem olid sellest pisikust nakatatud enamasti intelligentsi esindajad, siis minu päevil levis nakkus rahvaülikoolide, suveülikoolide, konkreetsete soomlastest Eesti-aktivistide, Põhjamaa Eesti Seltsi ja Tuglase Seltsi kaudu laiemalt rahva sekka. Tundsin end Oulus sellise välismaalasena, keda ei võõrastatud, kes tuli sinna küll monstrumliidu kodanikuna, aga lahkus Eesti Vabariigi kodanikuna ja kes võeti üsna tööaja alguses omaks. Suhted kahe riigi vahel muutusid 
ju kiiresti ja kardinaalselt. Tärkasid taas vana hõimuliikumise ideaalid, hakati toetama soomepoisse, kirikutes tehti korjandusi eesti kirikute ülesehituseks jpm. Mul oli suur rõõm selles protsessis osaleda, oma tagasihoidliku isikuga Eesti taassünnile kaasa aidata.

\section{Mida õppisid juurde, mida saab kasutada tulevases töös?}

Ei saa öelda, et oleksin Oulust kaasa saanud midagi konkreetset, mida edaspidises õppetöös Tartus kasutada. Õpetatavad kursused olid erinevad. Hakkasin lugema sissejuhatust eesti keele uurimisse, eesti õigekeelsust, kirjakeele sõnavara jm. Kindlasti oli mul Oulust tulles suurem ja parem lugemus, tundsin kirjandust, oskasin näitlikke õppevahendeid paremini kasutada, õppisin Oulus täpsemalt aega planeerima jpm.

1992. aasta kevadel korraldasid kolleegid mulle uskumatult toreda ja liigutava lahkumispeo, lauldes ette omaloomingulise serenaadi:

Valvelle

Joku tuumaili toimistossa, se oli kai Korpela, että serenadi sulle tähän juhlaan ois sopiva. Ja me mietimme yhteisesti, kuinka oot sinä mukava ja kuinka sinun lähtös on menetys valtava.

Joku tuumaili aiemminkin, se oli kai Sulkala, että sinussa vaikka mihin on ytyä, ainesta.

Ja tarmoa energiaa sinä paljon omistat ja lämmintä viehkeyttä, jolla kaiken somistat. 
Joku sanaili vielä sitä, se oli kai Mantila, että sinusta myöskin näkyy tosi elämäniloa.

Sielta hopeisten kutrien alta sinisilmäsi loistavat ja myönteisen luonteesi meille yhä uudestaan toistavat.

Joku huokaili haikeana, se oli kai Pääkkönen, että vaikeita on löytää meidän sinulle vertainen.

Olet säilyvä joukossamme, aina mukava muistona ja toivomme näkevämme sinut usein täällä vieraana.

Mida teeksin teisiti nüüd? Ei midagi. Kordaksin elatud aastaid heameelega uuesti. Aga seda ju ei saa. Aeg teeb meie kõigiga oma töö ja olen minagi jõudnud sinnamaale, kus elatud aastad kangastuvad vaid mälestuste sinavas kauguses. Olen õnnelik, et Oulust tagasi tulles oli mul alles armas kodu, abikaasa ja lapsed, juurde sündinud lapselapsed, kelle elu aitas mu Soome teenistus tookordsetes ülikitsastes majandustingimustes inimväärsemalt korraldada. Rõõmu teeb, et mu järglaseks Oulus sai igas mõttes õige inimene Heli Laanekask, kes jätkas eesti keele ja kultuuri õpetamist asjatundlikult, sügavuti ja tänapäevatasemel, suure pühendumuse ja vastutustundega, eeskujuliku vaimu- ja südameharidusega. 


\title{
Teaching Estonian in Oulu
}

\author{
VALVE-LIIVI KINGISEPP
}

In the spring of my last year in Oulu, together with the Finnish and Saami departments, we organized an Estonian language day to celebrate the 25th anniversary of Estonian instruction at the University of Oulu. We invited all the previous Estonian language instructors to speak and I asked them each to prepare answers to ten questions which seemed important to me at the time. Years later, my successor Heli Laanekask asked me to answer the same questions. I did so and am now sharing my impressions with our readers.

Thinking back on my years in Oulu, I recall many vibrant personalities, institutions, events, and celebrations, and I am overcome with nostalgia, because I remember those times as some of the most meaningful, interesting and eventful years of my life, which I could write about at great length accompanied by pictures, letters, documents etc.

Keywords: teaching Estonian to Finnish people; Estonian-Finnish cultural relations

\section{Valve-Liivi Kingisepp}

Tartu Ülikooli eesti ja üldkeeleteaduse instituut

Jakobi 2

51014 Tartu, Estonia

valve@neti.ee 